\title{
COMPETITION IN TAXATION AND THE FORMS OF ITS IMPLEMENTATION AMONG THE SUBJECTS OF THE RUSSIAN FEDERATION
}

\author{
Marija A. Troyanskaya \\ Orenburg State University, Orenburg, Russian Federation \\ ORCID 0000-0003-4545-3786
}

\begin{abstract}
The article considers competition in taxation as the condition for territories' development and the forms of its implementation among regions. Studies of the theoretical aspects of competition in taxation emergence allowed concluding that primarily social relations are its basis. The author defines the concept of competition in taxation as the process of competitive privileges regulation while dealing with public law establishments to share the tax base by attracting mobile production factors and other advantages to achieve sustainable competitiveness. The author also adds her own features to the classification of competition in taxation. The application of this classification helps deeper understanding of this phenomenon in its versatility. Considering tax competition among the Russian Federation subjects in finance-budget sphere allowed seeing several stages in the development of competence in taxation among regions from its implementation through violence to the correct application of fiscal policy tools. The research revealed the main prerequisites of the development of regional competition in taxation in Russia, and provided the ways and measures of its regulation among the RF regions by the state. The duality of the implementation of regional taxation competition's inner potential is demonstrated through the main directions of its ultimate impact via the fiscal and regulation functions. Considering the forms of the implementation of tax competition among the RF regions provided the opportunity to prioritize among the regional taxes, which allow influencing the competitive advantages of the territories in order to attract investors in their regions. The review of the regulations of all regional authorities allowed making a conclusion about the existence of different positions on participation in competition in taxation. The research demonstrated that most efficient and available forms of taxpayer involvement are establishing additional benefits on regional taxes, differentiation of the income tax rate (its regional part), and that most regions using the tools of competition in taxation bet on the increase of investment attractiveness of their territory

\section{KEYWORDS}

Competition in taxation, tax competition, classification of tax competition, types of tax competition, the forms of tax competition implementation

\section{HIGHLIGHTS}

1. Competition in taxation is the process of regulation of competitive privileges in the process of social establishments interaction aimed at the sharing of tax bases at the expense of involving mobile production factors and other advantages in order to achieve and keep sustainable competitiveness

2. It is expedient to add two more characteristics - the parameters' size and the vector of the impact - to the tax competition classification

3. The vertical tax competition by offering tax benefits has objective limitations at the present stage in the Russian Federation

4. There are various positions among the subjects of the Russian Federation on participating in tax competition, most regions rely horizontal competition in taxation through the means that support investment activity at their territory
\end{abstract}




\title{
КОНКУРЕНЦИЯ В СФЕРЕ НАЛОГООБАОЖЕНИЯ И ФОРМЫ ЕЕ ПРОЯВАЕНИЯ МЕЖАУ СУБЪЕКТАМИ РОССИЙСКОЙ ФЕАЕРАЦИИ
}

\author{
М. А. Троянская \\ Оренбургский государственный университет, г. Оренбург, Россия \\ ORCID 0000-0003-4545-3786
}

\begin{abstract}
АННОТАЦИЯ
В статье рассматриваются конкуренция в сфере налогообложения как условие развития территорий и формы ее проявления между регионами. Изучение теоретических аспектов возникновения налоговой конкуренции позволило сделать вывод о том, что ее базой в первую очередь являются общественные отношения. Сформулировано авторское определение конкуренции в сфере налогообложения как процесс регулирования конкурентных привилегий при взаимодействии публично-правовых образований за распределение налоговой базы за счет привлечения мобильных факторов производства и других преимуществ с целью достижения и сохранения устойчивой конкурентоспособности. Дополнена авторскими признаками видовая классификация налоговой конкуренции, практическое применение которой способствует глубинному пониманию данного явления во всей его многогранности. Рассмотрение содержания налоговой конкуренции субъектов РФ в сфере финансово-бюджетных отношений дало возможность определить, что налоговая конкуренция между регионами прошла в своем развитии несколько этапов - от реализации методом физического насилия до грамотного использования инструментов фискальной политики. В ходе исследования выявлены основные предпосылки развития региональной налоговой конкуренции в России и выделены методы и меры государственного регулирования налоговой конкуренции между субъектами РФ. Показана двойственность реализации внутреннего потенциала региональной конкуренции в сфере налогообложения посредством основных направлений ее конечного действия через фискальную и регулирующую функции. Рассмотрение форм проявления налоговой конкуренции между субъектами РФ дало возможность выделить приоритеты в отношении региональных налогов, которые позволяют оказывать влияние на конкурентные преимущества территорий с целью привлечения инвесторов в свои регионы. На основе обзора нормативно-правовых актов всех региональных органов власти сделан вывод о присутствии у субъектов РФ различных позиций по вопросу участия в конкуренции в сфере налогообложения. В работе показано, что наиболее действенными и доступными для регионов формами привлечения налогоплательщиков на свою территорию являются установление дополнительных льгот по региональным налогам, дифференциация ставки по налогу на прибыль (региональной части), большинство регионов при использовании инструментов налоговой конкуренции делают ставку на повышение инвестиционной привлекательности своей территории
\end{abstract}

\section{КЛЮЧЕВЫЕ СЛОВА}

Конкуренция в сфере налогообложения, налоговая конкуренция, классификация налоговой конкуренции, виды налоговой конкуренции, формы проявления налоговой конкуренции

\section{ОСНОВНЫЕ ПОЛОЖЕНИЯ}

1. Конкуренция в сфере налогообложения это процесс регулирования конкурентных привилегий при взаимодействии публично-правовых образований за распределение налоговой базы за счет привлечения мобильных факторов производства и других преимуществ с целью достижения и сохранения устойчивой конкурентоспособности

2. Классификацию налоговой конкуренции следует дополнить двумя признаками - размер параметров конкуренции и вектор ее воздействия

3. Вертикальная конкуренция путем предоставление льгот по налогам на современном этапе в Российской Федерации имеет объективные ограничения

4. У субъектов Российской Федерации наблюдаются различные тактики участия в налоговой конкуренции, при этом большинство регионов делают ставку на горизонтальную конкуренцию с помощью мер, поддерживающие инвестиционную деятельность на своей территории 


\section{Introduction}

The category "competition" is basic in the theory of economics. Today competition is a feature characteristic of any sphere of social life - economy, as well as politics and science. The experience of competition has been accumulating for many years; various theories and research about proper competitive behavior were developed. Initially the phenomenon of competence showed off solely in human relations. Such a model of behavior was often fruitful, and encouraged the improvement of human behavior in society. As the trade relations were developing, competition began to form among merchants and further went to tax relations. This fact allows tracing the genesis and the extension of the category and concept system of competition (Figure 1).

Figure 1 allows to conclude that the basis for any competition is primarily social relation, giving birth to social competition, which is defined by Ludwig von Mises as "some aspiration of individuals to have the most favorable position in the system of social cooperation" and which "exists in any imaginable way of social organization" [1, p. 138]. Further economic competition occurs in the process of social competition, and tax competition becomes a part of it later.

\section{Literature}

The phenomenon of tax competition, being an argument to achieve justice in the process of budget redistribution among states as well as inside one country, is un- derstood ambiguously and is studies insufficiently. There are different positions among the representatives of foreign and Russian science referring to the nature of tax competition (E. Janeba, St. Osterloh [2, p. 90], H. Ogawa [3, p. 7], J. Pi, Yu Zhou [4, p. 105], S. Winter [5, p. 140], S. Brangewitz, S. Brockhoff [6, p. 5], T. E. Olsen, P. Osmundsen [7, p. 1580], Yu. Han, P. Pieretti, B. Zou [8, p. 508], G. D. Wilson, and D. E. Waldaxin, A. A. Yakovlev, and V. F. Lapo [9, p. 29, 30], T. D. Goodspeed [10, p. 582], T. F. Field [11, p. 1211-1216], A. I. Pogorletskiy [12, p. 126], A. M. Puzin $[13$, p. 40], Y. B. Ivanov [14, p. 6], N. A. Leonova, G. V. Kolesnik [15, p. 83], O. Y. Bozulenko [16, p. 44], M. P. Pinskaya [17, p. 8], N. N. Laychenkova [18, p. 54], Encyclopedia... [19, p. 93]).

If one considers taxes as the price for the services offered by the state, then one should talk about the competition of offered social benefits concerning tax relations. In this case competition in taxation might be offering social benefits of higher quality and with fewer costs by one social establishment more efficiently that by the representatives of another social establishment [20, p. 180].

Having systematized various opinions the author considers competition in taxation to be the process of regulation of competitive privileges in the process of social establishments interaction aimed at the sharing of tax bases at the expense of involving mobile production factors and other advantages in order to achieve and keep sustainable competitiveness.

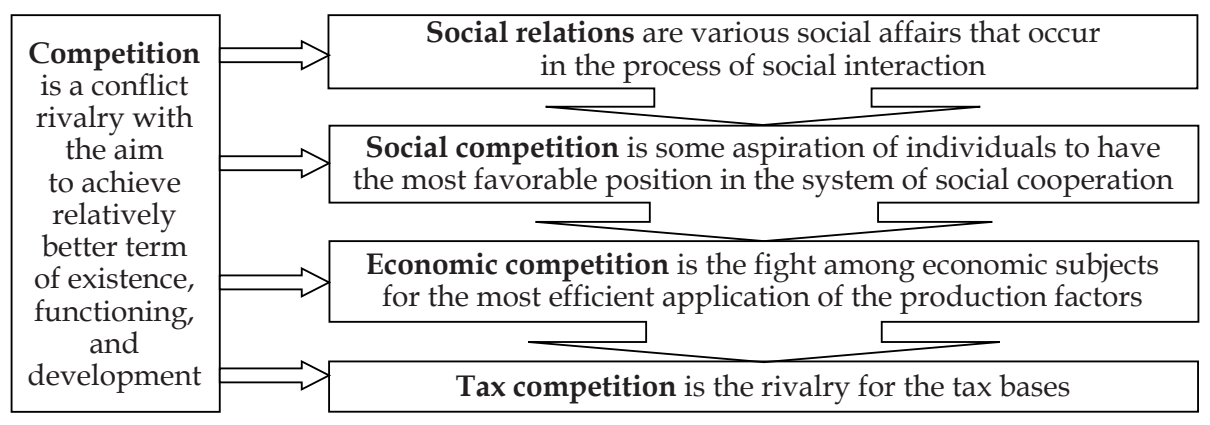

Figure 1. The genesis and extension of the category and concept system of competition 
Having considered opinions on competition and described economic views on tax competition in mind, we shall schematically depict (Figure 2) the general picture of conceiving the scientific thoughts about tax competition among regions.

Based on Figure 2 one might conclude that the phenomena of market and international competition are mostly studied at present. Economic competition and, consequently, tax competition which has been studies since the middle of the $20^{\text {th }}$ century occur with the development of market relations. For a long time, the scientists had thought that competition in taxation might show only in the process of interaction between the states, but recently the elements of tax competition have been seen more often between the regions.

\section{Outcomes}

The phenomenon of competition in taxation is fairly complex and multifaceted. However, there is no deployed classification of tax competition: many authors (M. R. Pinskaya [17, p. 14], A. I. Pogorletskiy [21, p. 4], T. V. Larina [22, p. 40], etc.) provide only fragmentary classification. Most researchers think that competition which exists in taxation is a form of economic competition. Thus, the author makes the classification of the types of tax competition based on the types of economic competition (Figure 3).

It is expedient to add two more characteristics - the parameters' size and the vector of the impact - to the tax competition classification given by various authors in order to make it more logically perfect. In accordance with the size of the parameters we can divide tax competition into factual, minimal, maximal, and optimal. Factual tax competition is the really achieved level of indicators in tax competition and competitiveness. Minimal level of tax competition is the level when the participation in competition becomes possible. It is the minimal level of tax release which can attract taxpayers. Maximal tax competition is the level of given tax release when the main objective of tax competition is reached but the bottom of competition is not reached. Optimal tax competition is the situation when the objective of tax competition is reached with minimal tax losses.

According to the second classification characteristics (vector of impact) tax competition is divided into initial and reached. The initial level is the first level of tax competition and competitiveness indicators which the subject has before making the decision on taking part in tax competition. Reached competition can be observed in a certain period of time after taking some actions about the participation in tax competition [20, p. 183].

It should be noted that recently the issue of the competition for tax payers has become relevant in Russia. In the end of 1990 with the start of economic growth in Russia the idea of the competition among the social establishments aimed at improving the efficiency of their economic development was actively promoted.

Budget decentralization is the reason for the competition in taxation among territories which allows taxpayers to choose

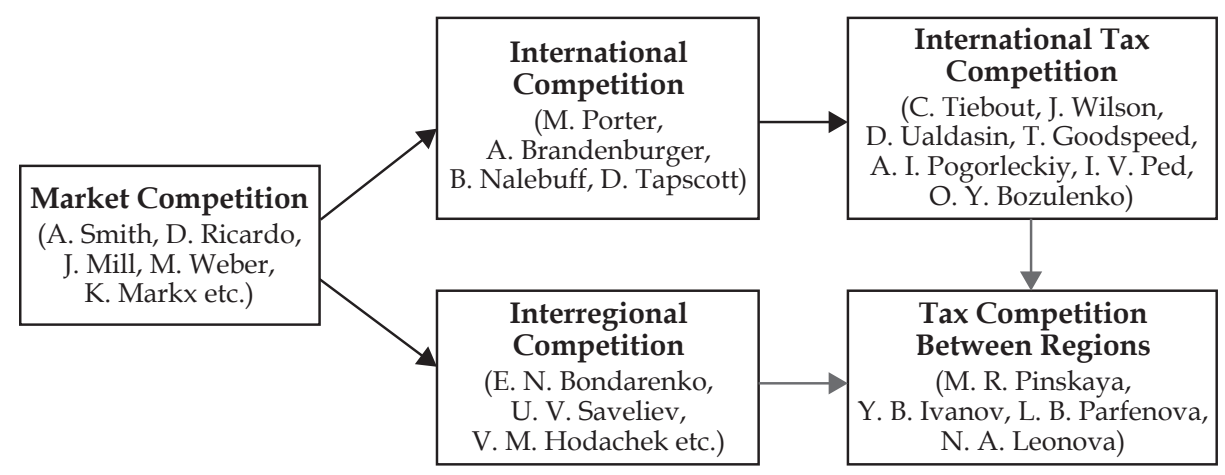

Figure 2. The origin of scientific thought on tax competition between regions 
the best position in minimal tax payments but at the same time leads to equal location of business entities oriented on the more favorable tax regime. The choice of the direction of social establishment's tax development determines further events held by the authorities directed to the improvement of territory's competitiveness, especially in the issues of taxation. It is obvious that the subjects of RF are interested in creating the advantages in their taxation system in comparison with other territories because taxpayers tend to select the region with the lowest tax load and wider range of tax tools to regulate their activity [25, p. 53].

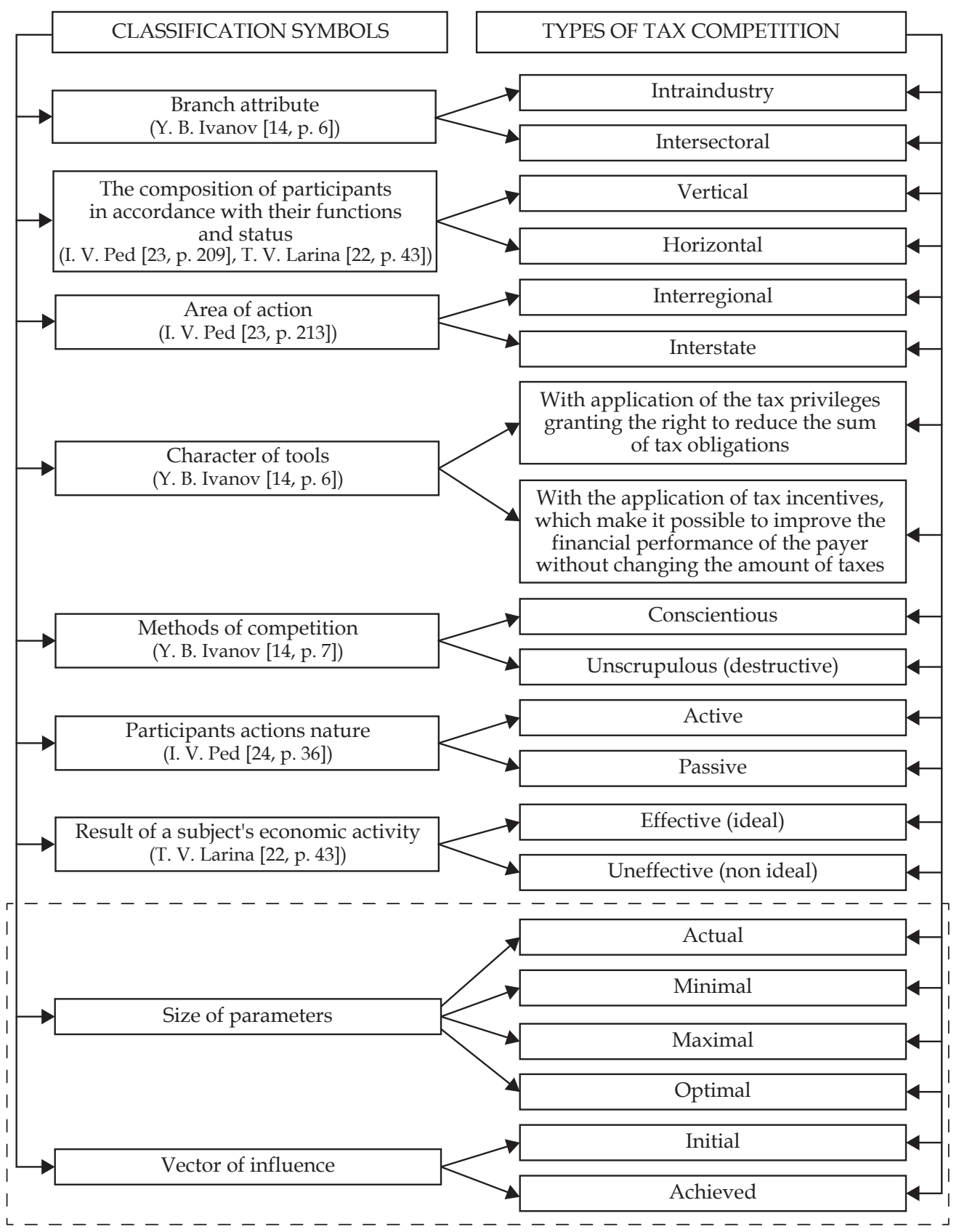

Figure 3. Specific classification of tax competition 
In Russia the competition in taxation among the regions has become popular rather recently. Figure 4 demonstrates the main prerequisites of the tax competition among the subjects of the Russian Federation.

Thus, one can see that the main factor of competition in taxation among the subjects of the Russian Federation is the transition to market economy. Geopolitical, and natural and climatic differenced of the regions also occurred before this period. However, they started to influence the development of the region sufficiently only after denying the plan economy.

The competitive environment in Russia formed not through evolution as in most developed countries, but through creating institutional conditions for the competitive behavior of the regions in taxation. For a short period of its presence tax competition among regions has demonstrated its advantaged and disadvantages (Table 1) [20, p. 183-184].

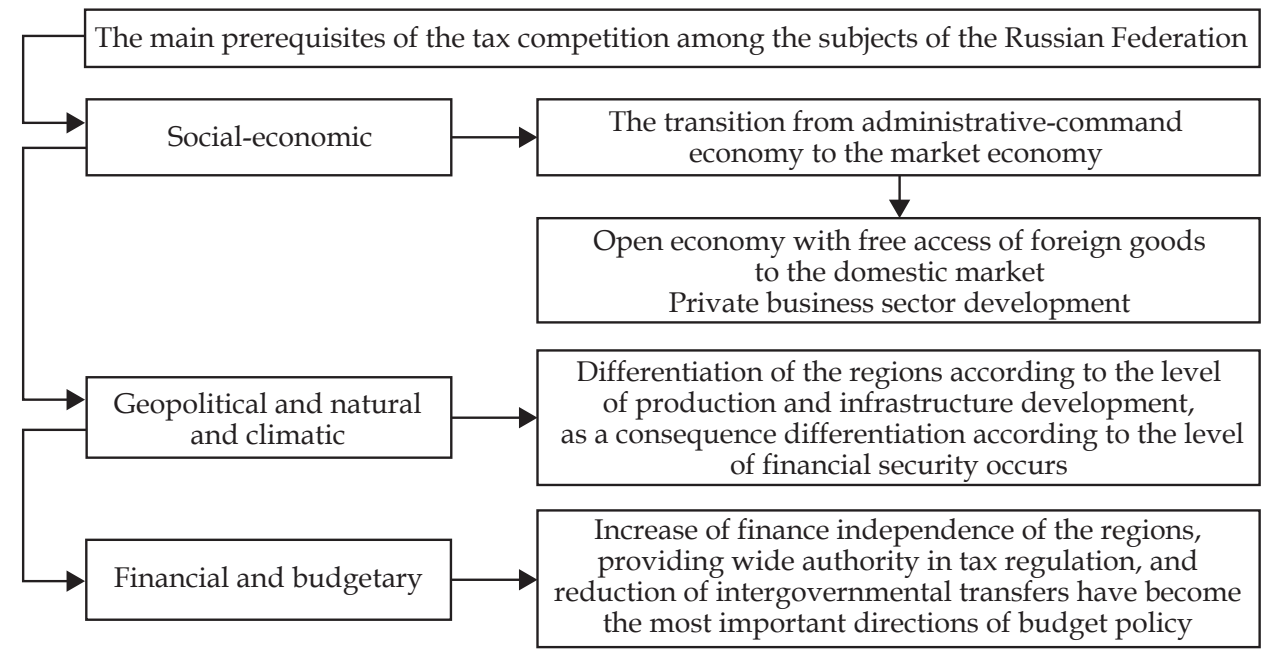

Figure 4. The main prerequisites of the development tax competition in the Russian Federation

\section{Advantages and disadvantages of competition in taxation among the subjects} of the Russian Federation

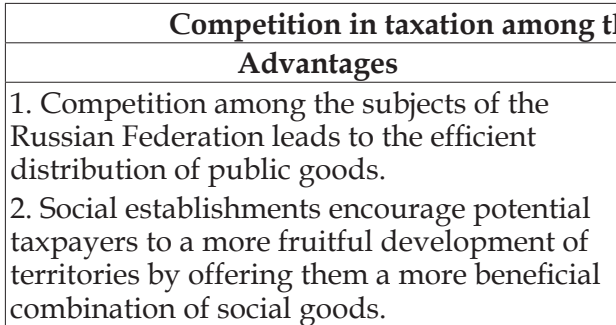

3. Authorities try to provide social goods having minimal level of taxation.

4. Improving competitive tax advantages (i.e. exclusive tax conditions which might attract taxpayers to the territory of the participant) provides the opportunity of tax revenue increase for the territory.

5. Reduction of the tax load for production factors which are quite mobile.

6. Framework type of state's impact on the economy and non-infringement of the democratic rights of the citizens

\section{1. "Underexposure" of the attracted tax} resources: the subject of RF compensates the tax revenue losses of the attracted tax resources at the expense of other (non-tax) resources or by enlarging the number of the imposed entities. 2. "Overexposure" of a certain taxpayer's category, which causes tax avoidance.

3. Tax competition causes ineffective results of authorities' activity - they try to decrease the tax rates to the level less that the level of their competitors to attract possible taxpayers and investors, which results in the "race to the bottom".

4. The subjects of RF are able to use the export of tax load.

5. Free competition among the subjects is able to destabilize the state market: regional authorities tend to offer social benefits to their residents only, offer tax benefits to the local capital, make trade barriers 
As one can see, tax competition among the subjects of RF has a sufficient number of the advantages and disadvantages. To generalize everything mentioned above we can conclude that there are two methods of implementing tax competition into tax management at the international level as well as at the level of the regions - voluntary and voluntary-forced (Figure 5).

The voluntary method presupposes that the subject independently makes the decision to improve its situation compared with other subjects. It develops various plots to improve its competitiveness and attractiveness for their "own" and "others" taxpayers. The voluntary-forced implementation of competition in taxation is a certain respond to the voluntary competition - the subject has to develop the events to participate in tax competition in order to keep subject's taxpayers, develop its competitive advantages. The voluntary-forced implementation of competition in taxation is also possible applying the tools of economic policy of the state, which cause the regions to provide themselves with their own financial resources via competition in taxation.

Figure 5 demonstrates the main means of the state to implement tax competition in Russia. As we have mentioned above, the first reason for competence in taxation in Russia to occur was the transition from administrative-command to market economy, which caused the development of private property. Then political events in the country and geopolitical factors determined the federate structure in Russia and the differentiation of its regions. After that the country became an active actor at

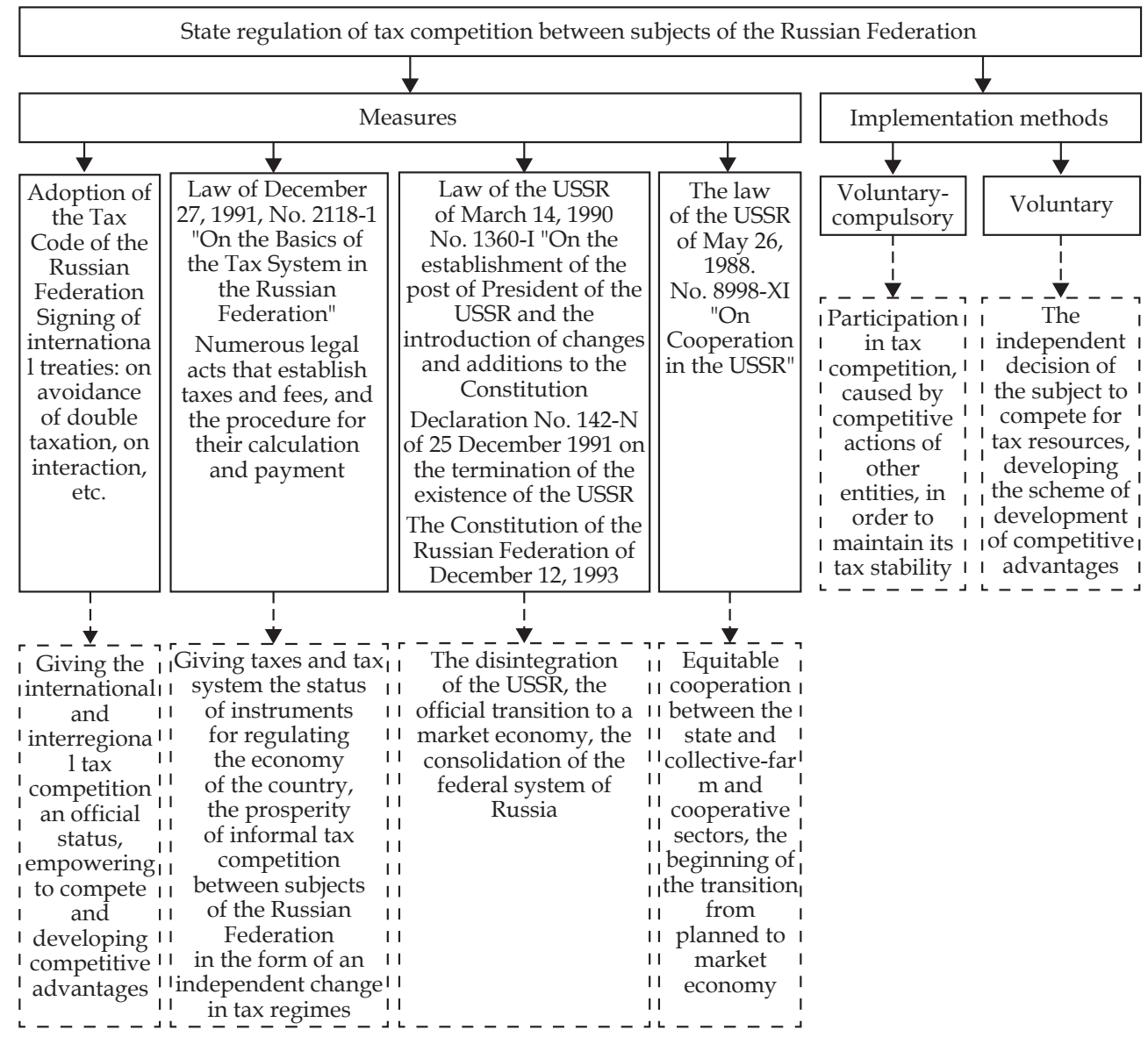

Figure 5. Methods and measures of state regulation of tax competition between subjects of the Russian Federation 
the global scene, which was the reason to participate in international tax competition, and the decentralization of financial resources inside the country was the reason for the development of international tax competition.

Competition in taxation among the regions mostly spreads in the countries with the federate structure of the territory due to regions' wider tax authority compared to the authority of a unitary state.

Tax rates, benefits and rewards for all or separate categories of taxpayers, other elements of taxation (taxpayers, the object, tax base, tax period, the order and the ways to pay tax) might be the tools of tax competition. It is advisable also to include into the tools of competition the simplified procedure of taxpayers' registration, and the simplified mechanism of the referral to a certain group to which a favorable tax regime is set.

We can classify the factors of changing the competition in taxation level based on the impact to the social-economic structure of the subject of the Russian Federation in the following way:

- objective (the principally new conditions of functioning are tax-budget reforming which means innovations in tax administration, regional governance organization using the achievements of science and practical experience in various sectors of economy);

- subjective (the decisions of the taxation agencies of the RF regions on providing financial aid to the regions, etc.) [26, p. 148];

- political (the ambitions of regional authorities to receive the advantages to form the tax revenue of the budget and to maximize the budget revenue without special priorities; no interest of the citizens to get and use the information on the part of regional political system functioning influencing the structure and the volume of social benefits financed on the expense of tax revenue) [26, p. 151];

- external (tax policy);

- internal (insufficient development of tax stimulation tools which might attract capital and labor resources to the territory of the RF subject);
- economic (reduction of tangible losses and, consequently, growth of financial activity result indicators; tax and nontax revenue, transfers among budgets, insufficient stimulation of territory's tax potential growth; reduction of tax risks; optimal tax load determination, improvement of taxes and fees management efficiency; proven application of tax benefits; capital and labor migration; investments);

- social (propensity to enrich by obtaining tax allowances and payments from the budget; state support; forming the environment of human capital development using tax and budget tools; inviting qualified experts; improvement of the tax culture level, etc.).

It is relevant to notice that T. Fild [11] while evaluating tax competition pays his attention to the necessity to distinguish and consider two more opinions - American and European. The author writes that the American and European judgements on the role of state in country's economy are different: the European judgements on tax competition are mostly negative in comparison with the US, which shows in the approach to study the phenomenon and in the relating protection measures. The European scientists and economists have an opinion that the state being a supplier of social benefits is entitled to protect its tax system from the devastating influence of competition in taxation. The American scientists, in turn, think that the volume of state expenses on social purposes demonstrates inefficiency and extravagance, thus tax competition is an essential tool of their decrease and economy development [20, p. 183].

Having pluses and minuses of competition in taxation among regions practically determines the dual nature of its economic potential. The inner potential of tax competition among regions is implemented through the fiscal and regulating functions of taxes. In the process of participating in tax competition these functions are able to interact according to the two plots: either they show simultaneously, or the fiscal function oppresses the regulating function minimizing the competition in taxation to zero. The reason for the first 
the more desirable for the regions variant of functions' interaction are the advantages of tax competition, and the second variant is possible when the disadvantages of tax competition occur.

The second plot of tax competition inner potential appearance is highly undesirable and even fatal for the social and economic development of the region. The first variant covers all the positive sides of the competition and makes a positive impact on legal entities and individuals.

The implementation of competition in taxation through the fiscal function results in investment attraction to the region, new employment, infrastructure development, and improving tax revenue. Its implementation through the regulating tax function encourages legal entities to develop small and middle size business and production stimulation. Referring to individuals it will improve savings, individual entrepreneurship initiative, the growth of people's individual income, etc.

The regional factor of the Russia Federation determines most processes in the system of state governance. Regions are the main link in the implementation of socialeconomic policy of the government. All the principal decisions of the federal center are more or less implemented via regional authorities. The daily interaction of the state with its citizens and most key questions of life support are solved at the regional level. Thus, the regions are the main element of modern Russian state mechanism. Simultaneously, the regions are the main form of economic and social life organization and the main totality of economic, social and demographic processes that exist in the country are localized there, the whole life cycle of the population is implemented here fully [27, p. 201].

The role given to the regions causes the necessity of their sustainable and efficient social-economic development as very important links in the system of social structure and state governance. The sustainability of the regions is the key condition to provide the national security of the country.

The main tool of governmental regulation of regions' social-economic development practically in all developed countries is tax regulation. The range of application of this tool in different periods of state development depends on their development stage. In the conditions of crisis and economic recession the role of the state and, therefore, of tax regulation increases. The state structure of Russia suggests the existence of three levels of power, so the tax system should also have three stages. The Tax Code of the Russian Federation determines the authority of all three levels of power bodies on taxation, implementation, changes and cancel of taxes. In connection with it there are federal, regional and local taxes in Russia. This distinction of the tax authority among the levels of power is called tax federalism.

The peculiarity of Russian tax budget system is high differentiation of the regions. The brightest examples of differenced in regions' social-economic indicators are given in Table 2 .

Examples of differences in the socio-economic development

Table 2 of the subjects of the Russian Federation

\begin{tabular}{|l|r|r|r|r|r|r|}
\hline $\begin{array}{c}\text { The subject } \\
\text { of the Russian } \\
\text { Federation }\end{array}$ & $\begin{array}{c}\text { Area of the } \\
\text { territory, } \\
\text { thousand } \\
\mathbf{k m}^{2}\end{array}$ & $\begin{array}{c}\text { Popula- } \\
\text { tion, } \\
\text { thousand } \\
\text { people }\end{array}$ & $\begin{array}{c}\text { Number of } \\
\text { enterprises } \\
\text { and orga- } \\
\text { nizations }\end{array}$ & $\begin{array}{c}\text { Average per } \\
\text { capita mone- } \\
\text { tary income per } \\
\text { month, rub. }\end{array}$ & $\begin{array}{c}\text { GRP, } \\
\text { million } \\
\text { rub. }\end{array}$ & $\begin{array}{c}\text { Incomes of } \\
\text { consolidated } \\
\text { budgets, } \\
\text { million rub. }\end{array}$ \\
\hline Moscow & 2.6 & 12197 & 1142555 & 54504 & 12808573 & 1552944.3 \\
\hline Orenburg region & 123.7 & 2001 & 40969 & 20724 & 731287 & 90088.8 \\
\hline $\begin{array}{l}\text { Nenets Autono- } \\
\text { mous District }\end{array}$ & 176.8 & 43 & 1127 & 66491 & 183699 & 19103.0 \\
\hline Republic Buryatia & 351.3 & 978 & 20309 & 22326 & 184815 & 50409.6 \\
\hline $\begin{array}{l}\text { Chukotsky Au- } \\
\text { tonomous District }\end{array}$ & 721.5 & 51 & 1178 & 57310 & 56556 & 21385.4 \\
\hline Republic Saha & 3083.5 & 957 & 26747 & 34205 & 660150 & 172332.9 \\
\hline
\end{tabular}


As one can see (Table 2), the square of the Republic of Sakha is 1186 times more than the square of Moscow, the number of population is 13 times less than the population of the Republic of Sakha, and the number of businesses and organizations in the Republic of Sakha is 43 times less than in Moscow, per capita money income in Moscow is 1.6 times more that in the Republic of Sakha. Similar situations can be seen comparing the figures of other regions.

Shall we imagine the forms by which use competition in taxation shows. The brightest is vertical tax competition by offering tax benefits. One should remember that application of the regulating function of competition in taxation is used with limits and locally because to be efficient the system of tax authority management having the role of a single and integral structure of forcible and compulsory tax relationships regulation must harmoniously implement an indivisible tax policy which, in turn, is positively taken by the society. Otherwise violation of the tax system unity and increase of tax avoidance may cause losses of tax revenue. It is important to consider the principles of different levels' authority division on the establishment of tax incentives which are used in Russia at present:

1. The right to impose and offer tax advantages (low tax rate, tax incentive, etc.) by one power level: "one tax - one level of power". In other words on power level manages the tax elements. For example, value added tax is the federal tax and goes to the federal budget, corporate property tax is regional and goes to the regional budget, personal property tax is local and goes to the local budget.

2. Dividing the right to state and give tax incentives to several power levels: "one tax - tree levels of power". In this case the tax revenue is divided between the budgets of tree levels of power and each power level is allowed to make its tax advantages. For example, corporate property tax is divided between the federal and regional budgets, and at the regional level the tax rate can be lowered and the investment tax credit can be offered.
3. The right to impose and offer tax incentives on state tax with the simultaneous dividing of tax revenues between the budgets of different levels. For example, the advantages on personal property tax are stated at the federal level, but the sum of state revenue is divided between the regional and local budgets [28, p. 52].

Horizontal competition in taxation can be seen through the means that support investment activity of the state, regions and municipalities. At the same time, the state makes the system of tax incentives to implement prioritized social-economic reforms. In turn, the main task of any state is to form institutional conditions which help to create and save favorable tax climate for investors. To reach this goal the incubators (economic centers) are formed where the organizations of leading economic activities are set up. These centers attract production factors. Concentration of money in the social establishments offering tax preferences provides the formation of the development axises.

The ability to offer tax advantages (incentives) is, no doubt, the main tool of tax regulation allowing to influence the competitive advantages of social establishments aimed to attract investors to their territories [29, p. 100]. It is possible to see the following advantages referred to the regional and local taxes in RF:

1. Deduction of certain tax objects, which have cost number and physical characteristics. Only the state bodies are allowed to offer this advantage.

2. Exemption from taxes to certain categories of taxpayers. Regional and municipal authorities are entitled to offer this advantage.

3. Decrease of tax rates. According to Art. 53 of the Tax Code of RF the authorities of the subject of RF and the local government are entitled to use this right given to them by the state. The example of such an advantage is corporate tax and a simplified system of taxation. In accordance with Art. 346.20 of the Tax Code of RF, the subjects of RF are entitled to offer the differentiated tax rates to the object "incomelosses" in the range from 5 to $15 \%$ with 
possible variation depending on the category of taxpayers and since 2016 to the object "income" from 1 to $6 \%$.

4. The change of the legally stated date of tax payment (to the later date by offering an investment tax credit, interest free loan, postponement). In accordance with Art. 63 of the Tax Code of RF the tax authorities of the subjects of RF are entitled to offer this advantage to the citizen interested to obtain it at the place of his/her location coordinated with certain tax authorities [28, p. 52-55].

It is important to pay attention to the dilemma which is the result of the competition in taxation character: on the one hand, it is performed to attract the taxable revenue to the territory of the social establishment, on the other hand - to receive investments and capital as well as the inflow of their owners. According to the theory, reduction of taxes to the minimal size may cause the inflow of capital to the economy of the social establishment and at the same time to attract investments. It is necessary to have a good infrastructure and highly qualified labor resources, which is the result of the social sector development funded by significant tax revenues. At the same time, their decrease to lower than the optimal possible level undermines the tax base and deteriorates the infrastructure, which might mean the outflow of the attracted investments in the nearest future [30, p. 32].

Having considered all the above, one can conclude that at present there is vertical and horizontal competition in taxation in the Russian Federation. Due to the limited and local application of vertical competition, horizontal competition, which has been gathering pace recently, is most relevant. Natural and human resources, the production structure, infrastructure, environmental situation, etc. provide competitive advantages to social establishments. The formation of tax advantages for the taxpayers who operate at the territory of this social establishment has a special role. In connection with this it5 is important to analyze the competitive position of the subject of the Russian Federation at the modern stage [28, p. 53].
Offering tax incentives is the most relevant tax mechanism to ensure the competitiveness of the region. Russian experience confirms that due to the tax incentives influence the taxpayers tend to move to other regions rather actively. To demonstrate this analysis of granting tax incentives by all the subjects of the Russian Federation was done (Figure 6).

It is important to pay attention to the dilemma which is the result of the competition in taxation character: on the one hand, it is performed to attract the taxable revenue to the territory of the social establishment, on the other hand - to receive investments and capital as well as the inflow of their owners. According to the theory, reduction of taxes to the minimal size may cause the inflow of capital to the economy of the social establishment and at the same time to attract investments. It is necessary to have a good infrastructure and highly qualified labor resources, which is the result of the social sector development funded by significant tax revenues. At the same time, their decrease to lower than the optimal possible level undermines the tax base and deteriorates the infrastructure, which might mean the outflow of the attracted investments in the nearest future [30, p. 32].

Having considered all of the above, one can conclude that at present there is vertical and horizontal competition in taxation in the Russian Federation. Due to the limited and local application of vertical competition, horizontal competition, which has been gathering pace recently, is most relevant. Natural and human resources, the production structure, infrastructure, environmental situation, etc. provide competitive advantages to social establishments. The formation of tax advantages for the taxpayers who operate at the territory of this social establishment has a special role. In connection with this it is important to analyze the competitive position of the subject of the Russian Federation at the modern stage [28, p. 53].

Offering tax incentives is the most relevant tax mechanism to ensure the competitiveness of the region. Russian experience confirms that due to the tax 

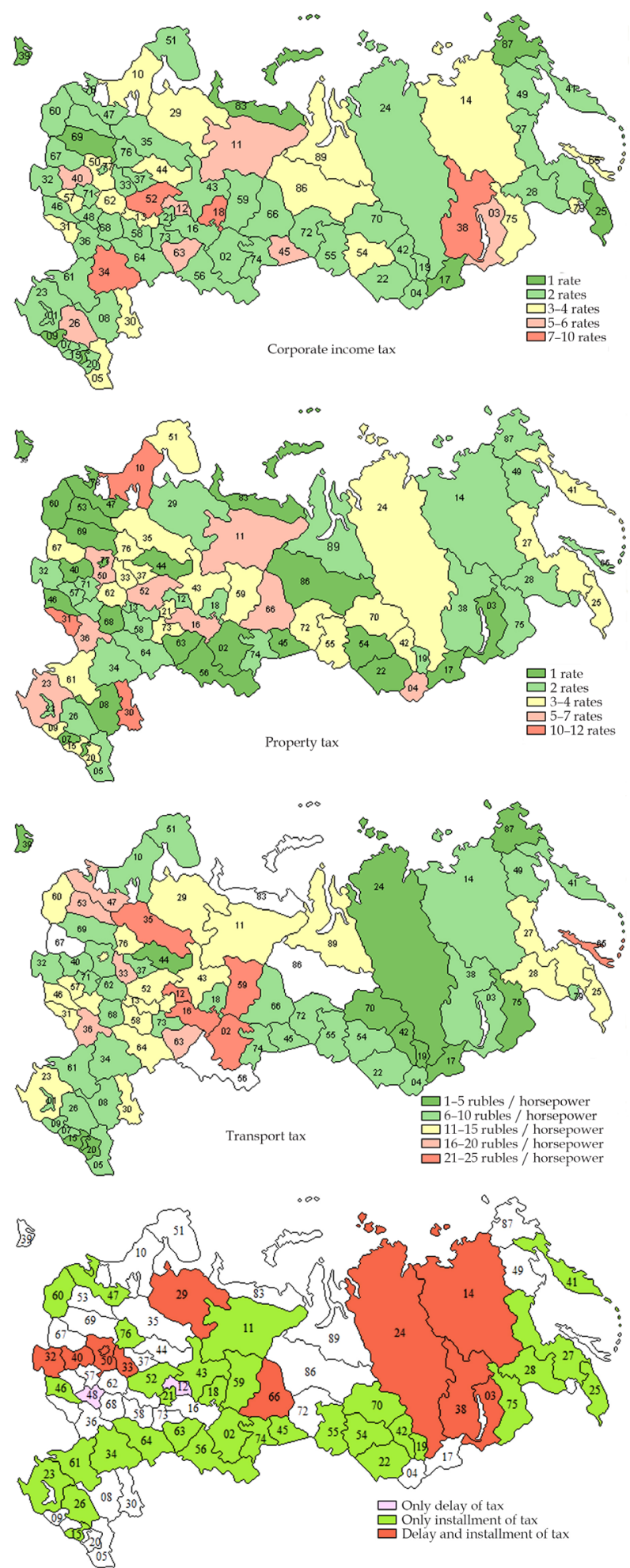

Figure 6. An example of the exercise of authority by the subjects of the Russian Federation on the use of instruments of tax competition in order to ensure the competitiveness of the region 
incentives influence the taxpayers tend to move to other regions rather actively. To demonstrate this analysis of granting tax incentives by all the subjects of the Russian Federation was done.

Figure 6 demonstrates the information on the monitoring of the legal acts of RF subjects and shows that the regions have various techniques relating to taxation. Most of the subjects of RF use their rights in taxation to create tax advantages (decrease income tax rate to not less than $4.5 \%$, use the differentiated scale of cor- porate tax rate and transport tax rate, offer free interest loans and postponements to pay taxes). At the same time, there are some territories that do not use this right. We must notice that most regions granted the right to use the decreased income tax rate for companies and corporate tax rate to the economies, which make investments. The division of tax rate also depends on the type of economic activity, the share of profit in the investment project which is subject to taxation, the volume of capital investments, etc. [28, p. 53].

Codes of subjects of the Russian Federation

\begin{tabular}{|c|c|c|c|c|c|}
\hline Subject name & $\begin{array}{c}\text { Subject } \\
\text { Code }\end{array}$ & Subject name & $\begin{array}{c}\text { Subject } \\
\text { Code }\end{array}$ & Subject name & $\begin{array}{c}\text { Subject } \\
\text { Code }\end{array}$ \\
\hline Republic Adygea & 01 & Stavropol Region & 26 & Omsk Region & 55 \\
\hline Republic Altai & 04 & Khabarovsk Region & 27 & Orenburg Region & 56 \\
\hline Republic Bashkortostan & 02 & Amur Region & 28 & Oryol Region & 57 \\
\hline Republic Buryatia & 03 & Arkhangelsk Region & 29 & Penza Region & 58 \\
\hline Republic Dagestan & 05 & Astrakhan Region & 30 & Pskov Region & 60 \\
\hline Republic Ingushetia & 06 & Belgorod Region & 31 & Rostov Region & 61 \\
\hline $\begin{array}{l}\text { Kabardino-Balkar } \\
\text { Republic }\end{array}$ & 07 & Bryansk Region & 32 & Ryazan Region & 62 \\
\hline Republic Kalmykia & 08 & Vladimir Region & 33 & Samara Region & 63 \\
\hline $\begin{array}{l}\text { Karachay-Cherkessia } \\
\text { Republic }\end{array}$ & 09 & Volgograd Region & 34 & Saratov Region & 64 \\
\hline Republic Karelia & 10 & Vologda Region & 35 & Sakhalin Region & 65 \\
\hline Republic Komi & 11 & Voronezh Region & 36 & Sverdlovsk Region & 66 \\
\hline Republic Mari El & 12 & Ivanovo Region & 37 & Smolensk Region & 67 \\
\hline Republic Mordovia & 13 & Irkutsk Region & 38 & Tambov Region & 68 \\
\hline Republic Sakha (Yakutia) & 14 & Kaliningrad Region & 39 & Tver Region & 69 \\
\hline Republic North Ossetia & 15 & Kaluga Region & 40 & Tomsk Region & 70 \\
\hline Republic Tatarstan & 16 & Kemerovo Region & 42 & Tula Region & 71 \\
\hline Republic Tyva & 17 & Kirov Region & 43 & Tyumen Region & 72 \\
\hline Udmurt Republic & 18 & Kostroma Region & 44 & Ulyanovsk Region & 73 \\
\hline Republic Khakassia & 19 & Kurgan Region & 45 & Chelyabinsk Region & 74 \\
\hline The Chechen Republic & 20 & Kursk Region & 46 & Yaroslavl Region & 76 \\
\hline The Chuvash Republic & 21 & Leningrad Region & 47 & Moscow & 77 \\
\hline Altai Region & 22 & Lipetsk Region & 48 & Saint Petersburg & 78 \\
\hline Transbaikal Region & 75 & Magadan Region & 49 & $\begin{array}{l}\text { Jewish Autonomous } \\
\text { Region }\end{array}$ & 79 \\
\hline Kamchatka Krai & 41 & Moscow Region & 50 & $\begin{array}{l}\text { Nenets Autono- } \\
\text { mous Okrug }\end{array}$ & 83 \\
\hline Krasnodar region & 23 & Murmansk Region & 51 & $\begin{array}{l}\text { Khanty-Mansiysk } \\
\text { Autonomous Ok- } \\
\text { rug - Yugra }\end{array}$ & 86 \\
\hline Krasnoyarsk region & 24 & $\begin{array}{l}\text { Nizhny Novgorod } \\
\text { Region }\end{array}$ & 52 & $\begin{array}{l}\text { Chukotsky Autono- } \\
\text { mous District }\end{array}$ & 87 \\
\hline Perm Region & 59 & Novgorod Region & 53 & $\begin{array}{l}\text { Yamalo-Nenets Au- } \\
\text { tonomous District }\end{array}$ & 89 \\
\hline Primorsky Krai & 25 & Novosibirsk Region & 54 & & \\
\hline
\end{tabular}




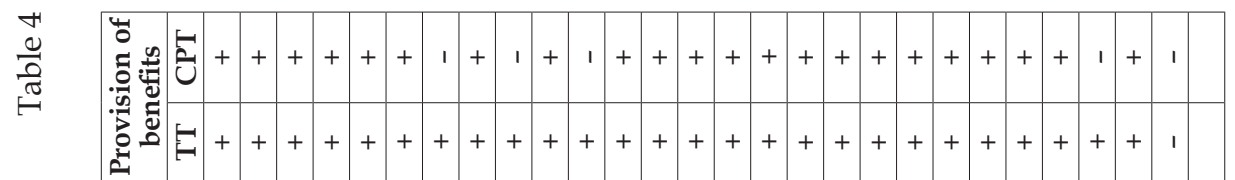

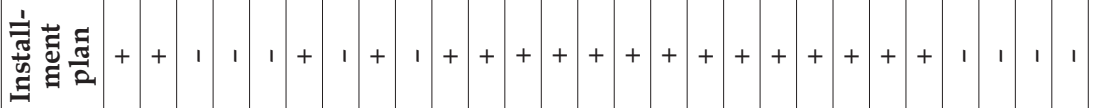

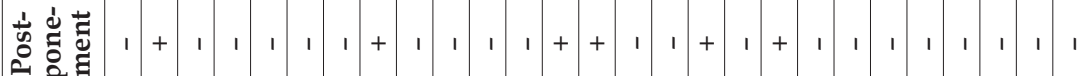

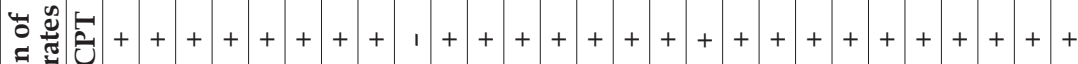

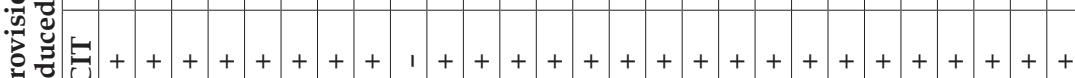

क

$\frac{\vec{U}}{2} \frac{\pi}{2}$

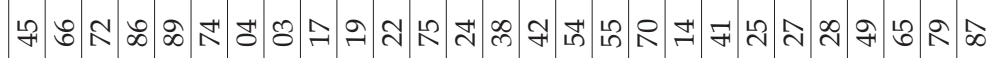

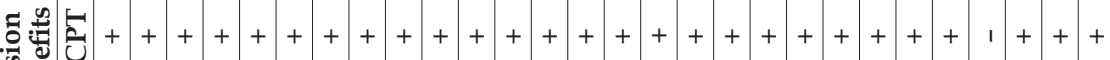

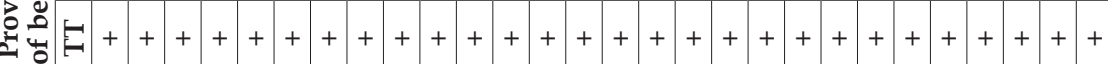

I

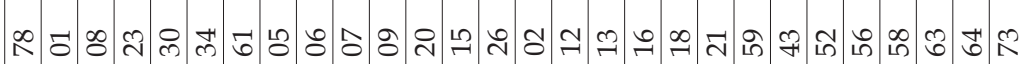

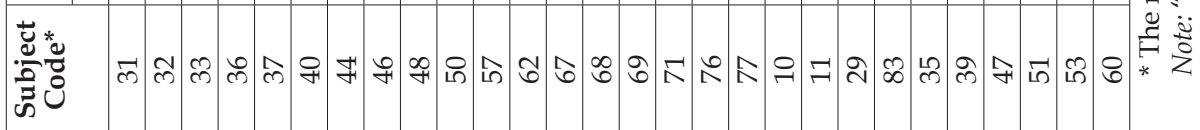


Table 4 is made based on the analysis of tax competition tools application. It demonstrates the degree of creating more advantageous conditions for taxpayers by the regions. The indicators of the given table show that there are no regions that do not apply the tools of tax competition. The Tyva Republic takes the least part in the regions' competition for tax resources and uses only one possible instrument.

\section{Conclusions}

The research of competition in taxation and its implementation forms among the subjects of the Russian Federation allows coming to the following conclusions:

1. Having in mind the formation of historical and practical prerequisites, the authors studied the origin of scientific thought on regional tax competition which is based primarily on social relation; provided their definition of the concept "competition in taxation" which differs from the existing theories where it is regarded within the frames of the process approach. The authors added their own characteristics to the species classification of tax competition based on the analogy method.

2. The authors defined that tax competition have gone through several stages of its development ranging from implementation through physical violence to the proper application of the fiscal policy tools.

3 . There are not so many forms of competition in taxation implementation for the regions in the existing Russian practice, which limits its full scale application in the territory of the country. The given review of the authorities 'regulations on their use of the tax competition tools testifies that there are various positions among the subjects of the Russian Federation on participating in tax competition. Most regions rely on the improvement of investment attractiveness of their territory.

The ultimate aim of the regional competition in taxation is to apply the reserves which improve the indicators of social and economic development, growth of the tax potential and the development of the taxation policy of a certain region as a result of comparing its indicators with other RF subjects.

\section{References}

1. Pinskaya M. R. Impact of Tax Competition on the Formation of Models of Tax Federalism. Vestnik Uralskogo gosudarstvennogo tekhnicheskogo universiteta-UPI = Bulletin of the Ural State Technical University-UPI, 2009, no. 4, pp. 138-143. (In Russ.)

2. Janeba E., Osterloh S. Tax and the City - A Theory of Local Tax Competition. Journal of Public Economics, 2013, vol. 106, pp. 89-100.

3. Ogawa H. When ad Valorem Tax Prevails in International Tax Competition. International Review of Economics \& Finance, 2016, vol. 46, pp. 1-9.

4. Pi J., Yu Zhou. Tax Competition in Federations Revisited. Economics Letters, 2014, vol. 123, iss. 1, pp. 104-107.

5. Winter S. Symmetric Tax Competition and Lobbying within Federations. European Journal of Political Economy, 2017, vol. 49, pp. 134-145. DOI: 10.1016/i.ejpoleco.2017.02.002.

6. Brangewitz S., Brockhoff S. Sustainability of Coalitional Equilibria within Repeated Tax Competition. European Journal of Political Economy, 2017, vol. 49, pp. 1-23.

7. Olsen T. E., Osmundsen P. Multinationals, Tax Competition and Outside Options. Journal of Public Economics, 2011, vol. 95, iss. 11-12, pp. 1579-1588. DOI: 10.2139/ssrn.1517198.

8. Han Y., Pieretti P., Zou B. An Extension of the Home-Attachment Criteria under Dynamic Tax Competition. Economics Letters, 2013, vol. 121, iss. 3, pp. 508-510. DOI: 10.1016/j. econlet.2013.10.007.

9. Shuvalova E. B., Klimovitsky V. V., Pusin A. M. Nalogovye sistemy zarubezhnykh stran [Tax Systems of Foreign Countries]. Moscow, Dashkov i K Publ., 2010. 134 p.

10. Goodspeed T. J. Tax Competition, Benefit Taxes, and Fiscal Federalism. National Tax Journal, 1998, vol. 51, no. 3, pp. 582.

11. Field T. F. Tax Competition in Europe and America. State Tax Notes, 2003, 31 March, pp. 1211-1216.

12. Pogorletskiy A. I. Russia's Tax Competitiveness in the Context of the Safe Development of Modern Society. Vestnik Uralskogo federalnogo universiteta. Seriya. Ekonomika i uprav- 
lenie $=$ Bulletin of the Ural Federal University. Series. Economics and Management, 2012, no. 3, pp. 125-134. (In Russ.)

13. Puzin A. M. Interstate Tax Competition: Sources and Prospects. Ekonomika, statistika $i$ informatika. Vestnik UMO = Economics, statistics and informatics. Bulletin of the UMO, 2010, no. 4, pp. 40-44. (In Russ.)

14. Ivanov Y. B., Chumakova O. O. Concerning Definition of Types of the Tax Competition. Ekonomika razvitiya = Development Economy, 2010, no. 1, pp. 5-8. (Ukrain.)

15. Leonova N. A., Kolesnik G. V. Evaluation of the Impact of Intergovernmental Fiscal Relations on the Nature of Tax Competition. Vestnik Tverskogo gosudarstvennogo universiteta. Seriya. Prikladnaya matematika = Bulletin of Tver State University. Series. Applied Mathematics, 2008, no. 11, pp. 83-92. (In Russ.)

16. Bozulenko O. Y. Concerning Regulation of the Tax Competition at the International Level. Ekonomist, 2008, no. 4, pp. 44-47. (Ukrain.)

17. Pinskaya M. R. Nalogovaya konkurentsiya: ot teorii k praktike [Tax Competition: from Theory to Practice]. Moscow, INFRA-M Publ., 2013. 136 p.

18. Lajchenkova N. N. Tax Competition as a Tool for Increasing the Efficiency of Regional Taxation and Tax Law. Informatsionnaya bezopasnost regionov = Information Security of Regions, 2015, no. 2 (19), pp. 53-56. (In Russ.)

19. Mayburov I. A., Ivanov Yu. B. (eds) Entsiklopediya teoreticheskikh osnov nalogooblozheniya [Encyclopedia of Theoretical Bases of Taxation]. Moscow, UNITY-DANA Publ., 2016. 503 p.

20. Troyanskaya M. A. Tax Competition: the Concept, Species, Meaning. Nalogi i finansovoe pravo $=$ Taxes and Financial Law, 2014, no. 6, pp. 179-185. (In Russ.)

21. Pogorletskiy A. I. International Tax Competition at the Present Stage of the World Economy Development. Problemi ekonomiki $=$ Problems of Economics, 2011, no. 2, pp. 3-9. (In Russ.)

22. Larina T. B. Analysis of the Grounds for the Existence of Tax Competition in the Subjects of the Russian Federation. Izvestiya vysshikh uchebnykh zavedenii. Seriya. Ekonomika, finansy i upravlenie proizvodstvom = Izvestiya Vysshikh Uchebnykh Zavedenii. Series: Economics, Finance and Production Management, 2011, no. 2, pp. 40-45. (In Russ.)

23. Ped I. V. Podatkova konkurentsiya [Tax Competition]. Kiev, Expert-Consulting Publ., 2009. $416 \mathrm{p}$.

24. Ped I. V. Modern Forms of the Tax Competition. Formuvannya rinkovikh vidnosin v Ukraïn $=$ Formation of the Market Relations in Ukraine, 2008, no. 11 (90), pp. 35-38. (Ukrain.)

25. Troyanskaya M. A. Development of Theories of Tax Competition as a Reflection of the Rivalry of Territories. Regionalnaya ekonomika: teoriya $i$ praktika $=$ Regional Economy: Theory and Practice, 2014, no. 25, pp. 48-54. (In Russ.)

26. Chuzhmarova S. I. Methodological bases of development of tax competitiveness of northern regions. Vestnik Uralskogo federalnogo universiteta. Seriya. Ekonomika $i$ upravlenie = Bulletin of the Ural Federal University. Series. Economics and Management, 2013, no. 2, pp. 145-155. (In Russ.)

27. Kireenko A. P., Orlova E. N. Manifestations of the Regional Tax Policy in the Conditions of Russian Budgetary Federalism. Region: ekonomika $i$ sotsiologiya $=$ Region: Economics and Sociology, 2014, no. 1 (81), pp. 193-217. (In Russ.)

28. Troyanskaya M. A. Monitoring of the use of Mechanisms of Tax Competition by Subjects of the Russian Federation. Finansy $i$ kredit = Finance and Credit, 2014, no. 33, pp. 51-60. (In Russ.)

29. Goncharenko L. I., Melnikova N. P. On New Approaches to the Policy of Applying Tax Incentives and Preferences in Order to Stimulate Economic Development. Ekonomika. Nalogi. Pravo = The Economy. Taxes. Right, 2017, vol. 10, no. 2, pp. 96-104. (In Russ.)

30. Parfenova L. B., Pugachev A. A. Tax Competition at the Subfederal Level as a Factor in the Development of the Region's Tax Potential in the Context of Russia's Accession to the WTO. Sbornik nauchnykh trudov Sworld = Collected Scientific Papers Sworld, 2012, vol. 21, no. 2, pp. 30-34. (In Russ.)

\section{Author}

Marija A. Troyanskaya - PhD in Economics, Associate Professor, Associate Professor of the Department of Finance, Orenburg State University, Orenburg, Russian Federation (13 Pobedy Avenue, 460018, Orenburg, Russian Federation); ORCID 0000-0003-4545-3786; e-mail: m_troyanskaya@mail.ru 


\section{Информация об авторе}

Троянская Мария Александровна - кандидат экономических наук, доцент, доцент кафедры финансов, Оренбургский государственный университет, г. Оренбург, Россия (460018, г. Оренбург, пр. Победы, 13); ORCID 0000-0003-4545-3786; e-mail: m_troyanskaya@mail.ru

\section{For citation}

Troyanskaya M. A. Competition in Taxation and the Forms of its Implementation among the Subjects of the Russian Federation. Journal of Tax Reform, 2017, vol. 3, no. 3, pp. 182-198. DOI: $10.15826 /$ jtr.2017.3.3.039

\section{Аля цитирования}

Троянская М. А. Конкуренция в сфере налогообложения и формы ее проявления между субъектами Российской Федерации / М. А. Троянская / / Journal of Tax Reform. - 2017. - T. 3, № 3. - C. 182-198. - DOI: $10.15826 /$ jtr.2017.3.3.039

\section{Article info}

Received October 1, 2017; accepted November 13, 2017

\section{Информация о статье}

Дата поступления 1 октября 2017 г.; дата принятия к печати 13 ноября 2017 г. 